\title{
Poeta imitatore czy poeta facitore? Późnorenesansowe włoskie dyskusje o mimesis
}

Krytyka mimesis rzadko kiedy kojarzona jest z estetyką dawną ${ }^{1}$ : antymimetyzm to wszak differentia specifica sztuki współczesnej. Sprzeciw wobec tradycyjnie pojmowanej mimezy we wczesnonowożytnej refleksji estetycznej wydać się może tendencją marginalną, ekskluzywną propozycją sformułowaną gdzieś na obrzeżach obowiązującej teorii, a nawet niechlubnym wyjątkiem potwierdzającym obligatoryjność doktryny mimetycznej. Estetyka wczesnej nowożytności (a również nowożytności w ogóle) jawi się jako przestrzeń jeśli nie absolutyzacji, to przynajmniej dominacji odziedziczonej po Arystotelesie koncepcji, utożsamiającej proces twórczy z aktem mimetycznym. Zdawać by się mogło, że postawiony przez Stagirytę znak równości pomiędzy pojęciami poesis a mimesis niezachwianie wyznacza kierunek renesansowego myślenia o poezji. Jednak doktryna mimetyczna względnym monolitem pozostaje jedynie do pewnego momentu. Stopniowo na powierzchni zintegrowanego systemu pojawiają się rysy i drobne pęknięcia, a w schyłkowej fazie Rinascimento w klasycznej teorii mimesis dostrzec już można pewien „wyłom”2 dokonany między innymi przez niepokornych teoretyków włoskiego Cinquecenta.

\footnotetext{
1 Niewiele jest w języku polskim studiów szerzej prezentujących ten aspekt estetyki późnego renesansu, choć oczywiście pisano niejednokrotnie o XVI-wiecznych przemianach w sposobie pojmowania mimesis. Zob. m.in. E. Sarnowska-Temeriusz, Przesztość poetyki. Od Platona do Giambattisty Vica, Warszawa 1995, s. 306-322; W. Tatarkiewicz, Historia estetyki, t. III, Warszawa 2009, m.in. s. 220-221; Id., Dzieje sześciu pojęć, Warszawa 1976, s. 318-326.

2 Nawiązuję tu do tytułu studium W. Tatarkiewicza, Pierwszy wytom w klasycznej teorii sztuki — manieryzm, „Życie i Myśl” 1967, nr 6, s. 1-11.
} 
W połowie XVI wieku, w dobie rozkwitu refleksji teoretycznoliterackiej i - co nieprzypadkowe - w okresie intensywnej recepcji Poetyki Arystotelesa, daje o sobie znać znamienna tendencja, którą trudno wprawdzie określić jako kontestatorską i stricte antymimetyczną, lecz z powodzeniem można ją potraktować jako zapowiedź późniejszych apoteoz poetyckiego kreacjonizmu. Najbardziej znamiennym wyrazem owej tendencji jest bezkompromisowa rozprawa Francesca Patriziego z Arystotelesowską mimesis, ale subtelne tony „antymimetyczne” pobrzmiewają również w mniej spektakularnych teoriach drugiej połowy XVI wieku ${ }^{3}$. Co najmniej niejasny, by nie powiedzieć — podejrzany, status doktryny mimetycznej odzwierciedla się czasem w tak, zdawałoby się, banalnym zjawisku jak wybory terminologiczne, które wyraźnie odsłaniają predylekcję późnorenesansowych teoretyków dla pojęć typu fingere i formare, akcentujących kreacyjny wymiar poetyckiej twórczości i niejednokrotnie zastępujących klasyczne imitare czy rappresentare.

Poza ostentacyjnie antymimetycznym wystąpieniem wspomnianego Francesca Patriziego właściwie trudno wśród teorii późnego renesansu wskazać koncepcje tak radykalnie manifestujące sprzeciw wobec doktryny naśladowania. Krytyka mimezy nie zawsze znajduje w wywodach teoretycznych wyraz demonstracyjny i jednoznaczny. Częściej pojawiają się dosyć enigmatyczne sygnały zdradzające, że arystotelesowska doktryna z jej naczelnym pojęciem jest niewystarczająca dla oddania istoty aktu twórczego. Kontestacja mimesis to w XVI wieku ekstremizm i jako taka jest rzeczywiście wyjątkiem. Ale pomiędzy awangardowym gestem ostatecznego odrzucenia a bezwarunkową akceptacją mimesis istnieje jeszcze przestrzeń pośrednia i to właśnie tutaj dokonują się istotne przewartościowania, które później doprowadzą do dyspersji teorii mimetyzmu. Zmiany w tradycyjnej, postarystotelesowskiej doktrynie mimesis dokonują się bardzo płynnie, dlatego też niełatwo, pominąwszy La deca disputata Patriziego (która zresztą nie zyskała szczególnie głębokiego oddźwięku), wskazać konkretną, autorską koncepcję, która zrewolucjonizowałaby refleksję teoretyczną. Trudno byłoby, nie narażając się na zarzut niekompetencji, utrzymywać że na przykład Benedetto Varchi i Paolo Delbene, którzy imitację zdecydowanie utożsamiali z działalnoś-

\footnotetext{
3 Problem włoskich koncepcji naśladowania, w tym atak Patriziego na Arystotelesowską mimesis, omawia dosyć dokładnie B. Hathaway, The Age of Criticism: The Late Renaissance in Italy, Ithaca-New York 1962, s. 3-23.
} 
cią fikcjotwórczą (fingere) ${ }^{4}$, opowiadali się tym samym przeciw mimezie jako takiej. W podobnych przypadkach (bo dwaj wymienieni wyżej nie są jedynymi, którzy eksplikując imitację, posługują się terminami fingere czy finzione) nieodparcie nasuwa się pytanie, czy tego typu definicje naśladowania można już uznać za afirmację twórczego wymiaru mimesis i konsekwentnie za negację jej aspektu reprodukcyjnego-odtwórczego?

Sami teoretycy nie dostarczają wprawdzie odpowiedzi całkowicie satysfakcjonującej, jednak pewne stosowane przez nich sformułowania wystarczająco wyraźnie sugerują, że preferowanym modelem mimetyzmu w okresie Cinquecenta jest naśladowanie równoznaczne z aktywnością inwencji i działaniami fikcjotwórczymi. Oto kilka prostych i znanych egzemplifikacji. Benedetto Varchi w połowie XVI wieku w swych florenckich Lezioni della poetica (opublikowanych w 1590 roku) naucza, czym jest naśladowanie, jednoznacznie identyfikując imitację z „wymyślaniem”, czyli tworzeniem fikcji (imitare cioè fingere) ${ }^{5}$. Pod koniec tegoż stulecia podobną myśl formułuje w swej skonwencjonalizowanej, szkolnej poetyce Jacobus Pontanus:

Imię poety pochodzi od „tò poiein”. Ponieważ słowo to tłumaczy się jak tworzyć i zmyślać (facere et fingere) - poeta przedstawia się nam jako twórca i zmyślacz czyli naśladowca (factor et fictor, sive imitator), a stąd poezja jako sztuka tworzenia i zmyślania czyli naśladowania. Zmyślanie bowiem lub wyobrażanie (fingere [...] seu effingere) jest naśladowaniem, mianowicie owej rzeczy, której obraz i podobieństwo się kształtuje; ten zaś kto naśladuje tworzy wyobrażenie czegoś $^{6}$

Poeta jest wprawdzie określony mianem imitator, co jednak nie znaczy, że jego twórcza aktywność ogranicza się do reprodukowania podobizn rzeczy istniejących, a skoro naśladowca to factor et fictor, można by sądzić, że swoboda poetyckiej inwencji i wyobraźni nie będzie niczym ograniczona. Tym bardziej można by się spodziewać, że nie będzie ograniczona kategorią podobieństwa. Jednak w renesansowych koncepcjach

4 Zob. B. Weinberg, A History of Literary Criticism in the Italian Renaissance, vol. I, Chicago 1961, s. 429, 534; W. Tatarkiewicz, Dzieje..., s. 320.

5 Cyt. za: B. Weinberg, op. cit., vol. I, s. 429.

6 Cyt. za: J. Pontanus, Prawidta poetyckie, z łaciny przełożył A. Guryn, w: Poetyka okresu renesansu. Antologia, wybór, wstęp i oprac. E. Sarnowska-Temeriusz, Wrocław 1982 , s. 485. 
imitacji, pomimo niewątpliwej dominacji Arystotelesowskiej, rewolucyjnej teorii probabilizmu, wciąż od czasu do czasu pobrzmiewa echo teorii Platońskiej, wraz z jej naczelnym kryterium oceny mimetyzmu wedle podobieństwa artystycznego wytworu do imitowanego modelu ${ }^{7}$.

Pontanus, niestety, daleki jest od pokus nowatorstwa i rewolucjonizowania teorii mimetycznej; pojęcia: „naśladowca”, „twórca” i „zmyślacz" są dla niego terminami pokrewnymi, a nawet ekwiwalentnymi, choć zrównanie tego typu zaledwie kilka lat wcześniej oburzało Francesca Patriziego. Aplikacja terminu fingere do definicji poezji nie pociaga za sobą automatycznie deprecjacji odtwórczych funkcji mimezy, zdradza jednak pewną modyfikację Arystotelesowskiej doktryny. Pojęcie mimesis dla XVI-wiecznych teoretyków oznacza nie tylko odtwarzanie rzeczywistości wedle reguł probabilizmu, ale także tworzenie i wymyślanie, nadal rygorystycznie ograniczone zasadą prawdopodobieństwa. Choć — jak wiadomo — w takim modelu mimetyzmu nie ma już miejsca na kategorię prawdziwości ${ }^{8}$, co poświadczają m.in. Alessandro Piccolomini, twierdząc, że prawda i fałsz to sprawy w poezji marginalne (,il vero adunque e il falso son cose accidentali alla poesia”) ${ }^{9}$, czy Philip Sidney, konstatując: "poeta niczego nie stwierdza i dlatego nigdy nie kłamie” („he nothing affirmeth, and therefore never lieth”) ${ }^{10}$.

Odniesienie do rzeczywistości i prawdy jest więc faktycznie nieistotne, co nie znaczy, że poezja przestaje być traktowana jako efekt działań naśladowczych. Przeciwnie — nadal jest naśladowaniem, choć już niekoniecznie realiów zewnętrznych, raczej wewnętrznych, fikcyjnych wytwo-

\footnotetext{
7 O platońskiej kategorii podobieństwa zob. G. Sörbom, Mimesis and Art. Studies in the Origin and Early Development of an Aesthetic Vocabulary, Uppsala 1996, s. 154. Dobrym przykładem zastosowania kryterium „podobieństwa” w wykładni mimetyzmu są choćby florenckie wykłady A. Segniego. Zob. Id., Lezioni intorno alla poesia, w: Trattati di poetica e retorica del Cinquecento, ed. B. Weinberg, vol. II, Bari 1972, s. $85 \mathrm{i} \mathrm{n.}$

8 O renesansowych koncepcjach prawdy i fałszu (oraz fikcji) w poezji zob. m.in.: C. Scarpati, E. Bellini, Il vero e il falso dei poeti. Tasso, Tesauro, Pallavicino, Milano 1990 (zwłaszcza rozdz. I: Vero e falso nel pensiero poetico del Tasso, s. 3-34); B. Hathaway, op. cit., s. 159-166; E. Sarnowska-Temeriusz, op. cit., s. 430-439.

9 A. Piccolomini, Annotationi nel libro della Poetica d'Aristotele, Vinegia, Presso Giovanni Guarisco e Compagni, 1575, s. 154.

10 Ph. Sidney, Selected Prose and Poetry, ed. by R. Kimbrough, Wisconsin 1983, s. 136. Jeśli nie zaznaczono inaczej, wszystkie przekłady tekstów źródłowych pochodzą od Autorki artykułu.
} 
rów twórczej wyobraźni. W 1555 roku Giovanni Pietro Capriano pisze, że poetyckie naśladowanie nie przedstawia prawdy, lecz jedynie wygląd rzeczy, jest imitacją tego, co zmyślone i symulowane („una rappresentatione di qualche cosa per apparenza, non del vero, che l'apparenza del vero imitatione non è, ma del finto e simulato" ${ }^{11}$. Ponownie zatem do definicji imitacji wkrada się pojęcie fikcji, wciąż doskonale uzgodnione z doktryną mimetyczną. Capriano jest wprawdzie głęboko przekonany o wartości kreacyjnego wymiaru poezji, twierdzi nawet, że „prawdziwi poeci muszą z niczego wymyślać swą poezję” („li veri poeti debbono di nulla fingere la lor' poesia”) ${ }^{12}$, jednak walory kreacyjności i fikcyjności nie są wedle niego sprzeczne z dogmatem mimetyzmu. Poetycka imitacja polega bowiem na „imaginacyjnej inwencji” (una imaginaria inventione) - wymyślaniu rzeczy, o których nie wiedziano nawet, że mogłyby istniećc ${ }^{13}$. Słowa włoskiego teoretyka brzmią nad wyraz innowacyjnie i wrażenie nowatorstwa pozostałoby zapewne niezakłócone, gdyby nie fakt, że afirmacja fikcji i inwencji zostaje wpisana w doktrynę mimesis. Najwyraźniej Capriano nie dostrzegał konieczności polemiki $\mathrm{z}$ tradycyjną teorią, uznając pojęcie mimesis za wystarczająco pojemne, by pomieścić również ów wysoko waloryzowany, fikcyjno-inwencyjny aspekt poetyckiej twórczości.

Wykładnia autorstwa Capriana, mimo pozorów nowatorstwa, jest raczej typowym przykładem późnorenesansowej koncepcji naśladowania, centralizującej pojęcia fikcji, kreacji i wyobraźni. Łączenie w obrębie doktryny mimesis koncepcji naśladowania probabilistycznego z fikcjotwórczą aktywnością imaginacji było znamienną tendencją w XVI-wiecznej refleksji teoretycznej ${ }^{14}$. Kierunkowi temu przeciwstawi się dopiero pod koniec wieku Francesco Patrizi, zdecydowanie odróżniając imitację od ekspresji, pojmowanej jako wyrażanie obrazów istniejących w sferze imaginacji twórcy:

11 G. P. Capriano, Della vera poetica, Vinegia, appresso Bolognino Zaltieri, 1555, k. A3. Szerzej o koncepcji naśladowania Capriana zob. B. Weinberg, op. cit., vol. I, s. 732-734; B. Hathaway, op. cit., s. 34-35.

12 G. P. Capriano, Della vera poetica, k. Biv.

13 Ibidem, k. Bv: „una imaginaria inventione [...] di qualche una cosa che tale à punto non si sappia giamai essere stata, o avvenuta".

14 E. Sarnowska-Temeriusz (op. cit., s. 318) pisze, że u schyłku renesansu naśladowanie jest „coraz chętniej ujmowane jako fikcja kreacjonistyczna”. Zob. też: W. Tatarkiewicz, Historia estetyki, t. 3, s. 220-221. 
Ma espressione non è imitazione, o se è non è propria del poeta, comune essendo a tutti gli scrittori e a tutti i parlatori. E sì come il pittore può co' suoi colori rassomigliare cosa di arte, o di natura, così però anche fingersi cosa che nè in arte nè in natura sia stata mai, ma fintasi di suo: nella primiera si dirà imitatore e rassomigliatore, ma non già sarà tale nella seconda, ma solo espressore della sua fantasia. Al pari sembra che il poeta possa e far ritratto simigliante a che che sia, e possa anche esprimere quelle immaginazioni che dentro di sè egli ha concepute, molte fiate a niuna delle cose o artate, o naturali, o divine, corrispondenti. ${ }^{15}$

Naśladowanie identyfikuje Patrizi z (re)produkcją wizerunków rzeczy istniejących, konsekwentnie więc miano naśladowcy przysługuje, jego zdaniem, wyłącznie temu artyście, który wytwarza kopie istniejących przedmiotów, odzwierciedlające podobieństwo do autentycznego modelu. Ten natomiast, kto kreuje wyobrażenia niemające ekwiwalentów w świecie realnym, nie może być nazywany imitatorem, jest bowiem jedynie wyrazicielem swej fantazji (espressore della sua fantasia). Ostra dystynkcja pomiędzy ekspresją, fikcją i imitacją sytuuje koncepcję Patriziego na przeciwległym biegunie w stosunku do wcześniejszych, XVI-wiecznych ujęć mimetyzmu. W ekstremistycznej teorii Patriziego nie ma miejsca nie tylko na utożsamienie naśladowania i twórczości poetyckiej, lecz także na identyfikację (czy nawet zbliżanie) naśladowania i fikcjotwórczych działań inwencji, tym bardziej na łączenie imitacji z aktywnością wyobraźni. Zakwestionowana zostaje heterogeniczna koncepcja mimetyzmu prezentowana m.in. przez Capriana, dla którego aktywność inwencji i imaginacji była komplementarną fazą poetyckiego naśladowania. Patrizi redukuje sens mimesis do odtwarzania rzeczy istniejących, sugerując, że imitacja i fantazja wzajemnie się wykluczają.

15 „Lecz ekspresja nie jest naśladowaniem, a jeśli jest, nie jest właściwa dla poety, będąc [aktywnością] wspólną wszystkim pisarzom i wszystkim mówcom. Tak samo malarz może za pomocą barw przedstawiać rzeczy podobne do sztuki lub natury, ale może także wymyślać rzeczy, których ani w sztuce, ani w naturze nigdy nie było, są jednak w jego wyobraźni: w pierwszym przypadku powie się, że jest naśladowcą i wytwórcą, ale nie w drugim: w tym przypadku jest tylko wyrazicielem swej fantazji. Wydaje się, że podobnie poeta może zrobić portret podobny do tego, kogo przedstawia, ale może też wyrażać fantazje, które w sobie wymyślił, a które nie mają odpowiedników ani w sztuce, ani w naturze, ani w rzeczach boskich" (F. Patrizi, Della poetica la deca disputata, w: Id., Della poetica, vol. II, edizione critica a cura di D. Aguzzi-Barbagli, Firenze 1970, s. 88). 
Argumentacja Patriziego jest nad wyraz logiczna i przekonywająca, ale jego bezkompromisowa delimitacja pomiędzy wyobraźnią, fikcją i artystyczną mimezą budzi pewne wątpliwości. Trudno uwierzyć, by antagonizm między fantazją i mimesis był istotnie aż tak głęboki, jak sugeruje włoski teoretyk. Faktem jest jednak, że późnorenesansowe polemiki z doktryną naśladowania mają swe antecedencje już w niektórych wątkach myśli antycznej, eksponujących twórczą dyspozycję phantasia i traktujących ją jako alternatywę dla mimesis. Nie znaczy to jednak, że pomiędzy tymi dwiema dyspozycjami widziano wyłącznie sprzeczność. Twórcza imaginacja, postrzegana jako władza niewątpliwie kreatywna, może wydawać się dyspozycją antagonistyczną w stosunku do reprodukcyjnych działań mimetycznych, ale z drugiej strony - z powodzeniem może być traktowana jako komplementarna faza procesu literackiej mimezy, co zresztą poświadczają liczne koncepcje, nie tylko późnorenesansowe.

Ambiwalencja pojęcia fantazji w kontekście teorii mimetycznej ujawnia się już w koncepcjach Platona. Początkowo negatywny stosunek filozofa do wyobraźni jako władzy tworzącej jedynie fantazmaty — pozbawione znaczenia, „niepewne i najczęściej mylne fikcje”16 w późniejszych dialogach ulega pewnemu złagodzeniu ${ }^{17}$. W perspektywie doktryny naśladowania najbardziej istotna jest dokonana w Sofiście symptomatyczna dystynkcja pomiędzy dwiema odmianami mimetyzmu - eikastycznym i fantastycznym. Mimesis eikastyczna, zdefiniowana jako umiejętność „wykonywania podobizn”, jest, wedle Platona, efektem działania wyobraźni odtwórczej (eikastike), skrupulatnie reprodukującej zmysłową strukturę modelu w mimetycznej kopii (eikon). Eikastyka — twierdzi Platon — „występuje wtedy, gdy ktoś, zgodnie z proporcjami modela w długości, szerokości i głębokości wykonywa jego naśladownictwo i nadaje mu w dodatku barwy odpowiednie dla każdej części"18. Natomiast wytworem mimezy fantastycznej, okre-

16 E. Wolicka, Mimetyka i mitologia Platona. U początków hermeneutyki filozoficznej, Lublin 1994, s. 24 (zob. też przyp. 8).

17 Zob. ibidem. Szerzej o Platońskiej teorii fantazji zob. A. Manieri, L’immagine poetica nella teoria degli antichi. Phantasia ed enargeia, Pisa-Roma 1998, s. 30-34.

18 Platon, Sofista 235E, w: Id., Dialogi, t. II, przeł., wstęp i objaśnienia W. Witwicki, Kęty 2005, s. 458. Na ten temat Platońskiej dystynkcji odmian mimesis zob.: J. Verdenius, Mimesis. Plato's Doctrine of Artistic Imitation and Its Meaning to Us, Leiden 1949, s. 21 i n.; R. McKeon, The Concept of Imitation in Antiquity, w: Critics and Criticism. 
ślonej mianem „umiejętności stwarzania złudnych wyglądów” (Sofista 236C), są kreatury fantazji, niepodobne do modelu fantazmaty, które za Gillesem Deleuze określić można jako „nieskończenie zdegradowane ikony"19.

Kryterium rozróżnienia mimezy eikastycznej i fantastycznej jest zatem nie tylko stopień podobieństwa mimetycznej kopii do modelu czy — inaczej mówiąc — poziom „ontologicznej asymetrii” ${ }^{20}$ pomiędzy obiektem reprezentacji a odwzorowaniem, ale także (a może przede wszystkim) rodzaj dyspozycji biorącej udział w procesie naśladowania. Jedna z dwóch obrazotwórczych władz duszy — odtwórcza eikastike bądź twórcza phantasia - jest czynnikiem decydującym o wartości reprezentacji, determinującym podobieństwo bądź — w wypadku aktywności fantazji — niepodobieństwo mimetycznej kopii do jej realnego modelu. Wedle koncepcji Platońskiej mimesis fantastyczna wytwarza „złudne wyglądy”, w istocie niepodobne do swych pierwowzorów, zwodzące tego, kto je postrzega z dystansu, generujące jedynie iluzję podobieństwa. Natomiast w myśl niektórych wykładni XVI-wiecznych rezultatem twórczej aktywności fantazji są rzeczy wymyślone „z niczego”, które nie muszą mieć autentycznych odpowiedników w świecie realiów. Platońskie kryterium podobieństwa w zastosowaniu do tak zdefiniowanych wytworów fantazji okazuje się całkowicie bezużyteczne. Podobieństwo do modelu jest, owszem, konstytutywną wartością „ikon” wytworów mimezy eikastycznej, kreatury fantazji natomiast nie mają już obowiązku odzwierciedlania czy imitowania realnego „wyglądu” przedmiotów. Nic dziwnego zatem, że rodzi się podstawowe pytanie nurtujące niektórych XVI-wiecznych teoretyków: czy obrazotwórczą aktywność fantazji można jeszcze określać mianem mimesis? Rozwikłanie tej kwestii, związane ze sposobem eksplikacji fantastycznej odmiany mimetyzmu, prowokuje interesującą polemikę.

W latach 70. XVI wieku Platońską dystynkcję komentuje Jacopo Mazzoni w traktacie Della difesa della Comedia di Dante, definiując na-

Ancient and Modern, ed. by R. S. Crane, Chicago 1952, s. 154-155; E. Belfiore, A Theory of Imitation in Plato's "Republic”, "Transactions of the American Philological Association”, 1984, 114, s. 131; E. Sarnowska-Temeriusz, op. cit., s. 44.

19 G. Deleuze, Platon i pozór, przeł. K. Matuszewski, „Principia” 21-22 (1998), s. 64.

20 M. P. Markowski, Pragnienie obecności. Filozofie reprezentacji od Platona do Kartezjusza, Gdańsk 1999, s. 23. 
Śladowanie eikastyczne jako wierną imitację przedmiotów istniejących „na zewnątrz”, poza sferą umysłu twórcy ${ }^{21}$, natomiast mimesis fantastyczną identyfikując z naśladowaniem przedmiotów wytworzonych przez imaginację. Wedle Mazzoniego, poeta-imitator realizujący mimesis fantastyczną nie naśladuje obiektów zewnętrznych, lecz wytwory swej imaginacji, kaprysy i fantazje („non imita ogetto posto di fuori, ma solo il capriccio e la fantasia sua") ${ }^{22}$ - imitazione fantastica jest więc - podobnie jak eikastyka - procesem mimetycznym, tyle tylko, że obiektem imitacji jest wewnętrzna zawartość duszy artysty, „wymysły" i obrazy wykreowane w sferze fantazji, a nie elementy świata rzeczywistego.

Z tej pozornie jednoznacznej wykładni u schyłku Cinquecenta czerpie inspirację teoretyk sztuki, przyjaciel Tassa, Gregorio Comani$\mathrm{ni}^{23}$, komentując w swym dialogu Figino Platońskie odmiany mimesis. Niebudzącą wątpliwości imitatione icastica określa jako tę, która wiernie naśladuje swe obiekty (,imita le cose le quali sono”), imitacji zaś fantastycznej przypisuje oczywiście zdolność wymyślania rzeczy nieistniejących („finge cose non esistenti”) ${ }^{24}$. Być może również pod wpływem dowartościowujących fikcyjny aspekt twórczości koncepcji Mazzoniego Comanini dochodzi do wniosku, że w poezji (inaczej niż $\mathrm{w}$ malarstwie $)^{25}$ model imitacji fantastycznej przewyższa niewolnicze naśladowanie eikastyczne choćby dlatego, że wytwory poetyckiej fan-

21 Por. „Mostra Platone [...] che l'imitazione può farsi in due modi. Il primo de' quali si è quando si vanno imitando le cose che sono fuori di nostro inteletto. Il secondo modo è quando l'imitatore non rappresenta, se non quelle specie che egli ha concette nella sua fantasia" (J. Mazzoni, Della difesa della Comedia di Dante, Cesena 1587, s. 394). Na temat koncepcji naśladowania fantastycznego w teorii Mazzoniego zob. B. Hathaway, op. cit., s. 120-125.

22 Ibidem.

23 O zależności wykładu Comaniniego od koncepcji zawartych w Della difesa Mazzoniego zob. komentarze wydawców w edycji: G. Comanini, The Figino or On the Purpose of Painting: Art Theory in the Late Renaissance, ed. by A. Doyle-Anderson and G. Maiorino, Toronto 2001, s. ix, xi, 112, przyp. 6. Sam zresztą Comanini niejednokrotnie w toku wywodów powołuje się na traktat Mazzoniego.

24 Cyt. za: G. Comanini, Il Figino overo del fine della pittura, w: Trattati d'arte del Cinquecento, vol. III, a cura di P. Barocchi, Bari 1962, s. 248.

25 Comanini twierdzi, że w malarstwie, inaczej niż w poezji, rzeczą wzbudzającą największy podziw i wymagającą od artysty większego, twórczego wysiłku jest wierne naśladowanie eikastyczne, odtwarzanie bowiem naturalnego podobieństwa modeli jest sprawą trudniejszą, wymagającą większego kunsztu malarskiego niż przedstawianie 
tazji wywołują silniejsze wrażenie, sprawiając czytelnikowi nieporównanie większą przyjemność niż, nawet idealnie imitowane, podobizny przedmiotów znanych z rzeczywistości. Zdaniem Comaniniego, dla generowania efektów podziwu i przyjemności istotne jest przede wszystkim to, że twórczość fantastyczna wymaga od poety większego wysiłku i zaangażowania niż realizacja zasad mimesis eikastycznej. W przypadku tej ostatniej poeta w nikłym stopniu angażuje swój umysł, dlatego też robi na odbiorcy mniejsze wrażenie niż wówczas gdy, aktywizując swą inwencję, kreuje fantastyczne wizerunki, doskonaląc tym samym ingenium i sztukę ${ }^{26}$. Delektacja towarzysząca percepcji wytworów naśladowania fantastycznego wynika więc nie tylko z samego waloru tego typu nowości przedstawień, jest przede wszystkim rezultatem podziwu dla artystycznych — twórczych — predyspozycji poety. Tworzenie na zasadach mimesis fantastycznej okazuje się zatem gwarancją estetycznej przyjemności. Trudno o bardziej dobitny przykład pokazujący, że kreacyjny wymiar działalności poety, aktywizujący inwencję i fantazję, jest u schyłku wieku XVI preferowany i ceniony nieporównanie wyżej niż naśladowcze „wykonywanie podobizn”.

Ani Mazzoni, ani Comanini nie mają wątpliwości co do tego, że artystę realizującego fantastyczną odmianę mimetyzmu nie zajmuje już reprodukcyjna imitacja rzeczywistości, ale twórcza ekspresja wyobrażeń (fantazji). Jednak świadomość znaczących różnic pomiędzy owymi odmianami tworzenia nie prowadzi teoretyków do całkowitego odrzucenia czy radykalnego przeformułowania odziedziczonej po starożytności doktryny mimetycznej akceptowanej przez obu z nielicznymi zastrzeżeniami. Oswojony z XX-wiecznymi manifestami antymimetycznymi czytelnik współczesny, śledząc subtelne egzegezy platońskich odmian mimesis u Mazzoniego czy Comaniniego, spodziewa się czegoś więcej niż samej pochwały mimezy fantastycznej: oczekuje przynajmniej deprecjacji naśladowania eikastycznego (reprodukcyjnego) na rzecz poetyckiego kreacjonizmu.

Tymczasem Mazzoni, choć przecież nader wysoko ceni poetyckie fikcje — produkty twórczej imaginacji, daleki jest od tego, by poecie tworzącemu wedle kaprysów fantazji odmówić miana naśladowcy,

fikcyjnych wytworów fantazji, niemających realnych odpowiedników. Zob. ibidem, s. 248

26 Ibidem. 
a poezji powstałej jako efekt działania imaginacji — nazwy mimesis. Wykorzystując autorytet Platona, teoretyk utwierdza siebie i swych czytelników w przekonaniu, że poezja zawierająca fikcję i będąca wytworem fantazji jest naśladowaniem, choć nie odzwierciedla prawdy lecz prawdopodobieństwo ${ }^{27}$. Tworzenie aktywizujące fantazję nie jest, w teorii Mazzoniego, modelem antagonistycznym w stosunku do tradycyjnie pojmowanego, odtwórczego mimetyzmu; to jedynie odmiana naśladowania, niewątpliwie bardziej kreatywna niż reprodukcyjna eikastyka, ale jednak, niestety, wciąż mimesis.

Nie może dziwić, że takiej wykładni fikcjotwórczego i kreacyjnego mimetyzmu nie był w stanie zaakceptować Francesco Patrizi, stawiający ostre granice między ekspresją fantazji a mimesis. Kilkanaście lat po pierwszej edycji traktatu Della difesa... Patrizi kwestionuje eksplikację Mazzoniego, również powołując się na Platona i z właściwą sobie logiką udowadniając bezzasadność identyfikacji fantazji z działaniami imitacyjnymi. Nieprzypadkowo właśnie w swej La deca ammirabile, będącej manifestem poetyki cudowności, z emfazą pisze:

Non neghiamo noi, però, che il poeta non formi specie e idoli nella sua fantasia che non hanno ogetto fuori, perchè per tali riconosciamo il Briareo, l'Argo, la Chimera e gli altri così fatti; neghiamo questa formazione essere la fantastica imitazione di Platone, e neghiamo anco del tutto che la tale formazione sia imitazione ${ }^{28}$.

Jak widać, proces artystycznej „produkcji” wyobrażeń określa Patrizi nobilitującym mianem formazione, wyraźnie przeciwstawiając tworzenie wedle fantazji imitacji, a więc mimezie obiektów zewnętrznych.

Włoski apologeta kategorii meraviglia, doskonale świadom tego, że efektywność cudowności ściśle wiąże się z kreacyjną aktywnością poetyckiej wyobraźni, nie jest w stanie przystać na identyfikację owej, konsekwentnie przezeń dowartościowywanej, dyspozycji twórczej z równie konsekwentnie postponowaną mimezą. Proponowana przez Mazzonie-

27 J. Mazzoni, Della difesa..., s. 16.

28 „Nie negujemy tego, że poeta formuje w swej wyobraźni wyobrażenia niemające odpowiedników w rzeczywistości, bowiem za takie uważamy Briareusa, Argusa, Chimerę oraz im podobne zjawiska; negujemy jednak to, że tego rodzaju stwarzanie jest tym samym co Platońska mimesis fantastyczna, a nade wszystko zaprzeczamy temu, że takie tworzenie jest naśladowaniem" (F. Patrizi, La deca ammirabile, w: Id., Della poetica, vol. II, s. 279). 
go ekwiwalencja pomiędzy imitacją a fantazją, sugerująca odtwórczość wyobraźni, niewątpliwie oznacza dla Patriziego deprecjację tej ostatniej. Teza o reprodukcyjności czy mimetyczności fantazji — zawarta implicite $\mathrm{w}$ stwierdzeniach Mazzoniego - automatycznie poddaje w wątpliwość kreacyjne funkcje wyobraźni, a przecież jej domeną ma być wytwarzanie zjawisk niezwykłych i zadziwiających. W myśl teorii Patriziego fikcjotwórcze działania imaginacji, polegające na formowaniu rzeczy nieistniejących, nie mają nic wspólnego z odtwórczą, bierną imitacją eikastyczną, która jedynie reprodukuje rzeczywistość, niwelując tym samym efekt nowości przedstawień, a to - jak wiadomo — niezbędny walor obrazów kreowanych na zasadzie poetyckiej meraviglia.

Fragment polemiki Patriziego z zaproponowaną przez Mazzoniego egzegezą Platońskiej mimesis fantastycznej prowokuje do tego, by twórczą aktywność fantazji potraktować jako dyspozycję opozycyjną wobec reprodukcyjnych działań mimetycznych. Jeśli jednak usytuujemy zjawisko fantazji w szerszym kontekście antycznej i renesansowej teorii mimetycznej, to okaże się, że działalność imaginacyjna niekoniecznie musi wykluczać aktywność imitacyjną, a wręcz przeciwnie — stanowić może integralną fazę wytwarzania mimetycznych kopii, zwłaszcza wówczas, gdy uaktywniona zostanie dyspozycja wyobraźni odtwórczej. Wszak to obrazotwórcza zdolność wyobraźni umożliwia kreację mimetycznych obrazów — zarówno ikonicznych, wiernych podobizn, jak i skiagraficznych, złudnych widziadeł. Fantazja, twórcza i aktywna, produkuje fikcyjne obrazy, wewnątrz siebie warunkując kreację fantastyczną, imaginacja odtwórcza natomiast czerpie podniety z dostępnego zmysłom świata realiów i dlatego dzięki niej „aktywność mimetyczna może wytworzyć obraz podobny do rzeczywistości"29.

Ta dualistyczna koncepcja wyobraźni dawała teoretykom renesansu dwie możliwości: z jednej strony wpisanie fantazji w ramy tradycyjnej doktryny mimesis, co zresztą praktykowano dosyć często, z drugiej dostrzeżenie w aktywności imaginacji aspektu kreacyjnego, wykraczającego poza typową odtwórczość mimezy. Postrzeganie fantazji jako dyspozycji przetwarzającej dane zmysłowe zapoczątkowała jedna z bardziej wpływowych wykładni zawarta w psychologicznych koncepcjach

29 J. Starobinski, Wskazówki do historii pojęcia wyobraźni, przeł. W. Kwiatkowski, „Pamiętnik Literacki” 63 (1972), z. 4, s. 220. O renesansowym rozróżnieniu wyobraźni aktywnej i odtwórczej zob. Sarnowska-Temeriusz, op. cit., s. 289-291. 
Arystotelesa, podkreślających bliskie koneksje wyobraźni ze światem sensibiliów. Fantazja traktowana na sposób arystotelesowski jako „ruch wywołany przez aktualne postrzeżenie” ${ }^{30}$ (przy założeniu, że „wyobrażenie [...] nie może powstać niezależnie od postrzeżenia”"31) może więc wydać się dyspozycją zupełnie pozbawioną pierwiastka kreacyjności. Stagiryta sformułował jednak również następujące twierdzenie: „wyobraźnia jest tym, przez co powstaje w nas jakiś obraz" (428a). I choć niekoniecznie należy doszukiwać się w tej myśli sugestii autonomicznej kreacji wyobrażeń, uniezależnionej od zewnętrznych, zmysłowych realiów, to niektórzy komentatorzy koncepcji Stagiryty wyraźnie preferują interpretację akcentującą twórczy wymiar imaginacji. Prócz Patriziego do takich będzie należał już później, bo w XVII wieku, choćby Emmanuele Tesauro, który w inspirowanej teorią Arystotelesa Filosofia morale potraktuje imaginację jako władzę asymilującą i przetwarzającą dane sensualne, ale równocześnie podkreśli, że jest dyspozycją transformującą wrażenia zmysłowe w obrazy o niezwykle żywych i intensywnych barwach $^{32}$. Fikcjotwórczą potencję wyobraźni na początku XVII wieku zaakcentuje również polski komentator Arystotelesa - Sebastian Petrycy z Pilzna, pisząc o władzy, którą "Grekowie fantazyją zowią” i stwierdzając, że „z tej władze pochodzi [...], że możem sobie wymyślić jaką rzecz, której na świecie nie masz"33.

Tak chętnie eksponowany w myśli późnego renesansu i baroku twórczy wymiar imaginacyjnej dyspozycji nie był całkowicie oryginalną, autorską propozycją nowożytnych teoretyków. Podstawowych źródeł inspiracji dla zwolenników kreacyjnego modelu naśladowania szukać trzeba w teoriach antycznych. Po pierwsze wykładnia Pseudo Longino-

30 Arystoteles, O duszy, 429a, w: Id., Dzieta wszystkie, t. 6, przeł., wstęp i kom. P. Siwek, Warszawa 2003, s. 123. Szerzej o Arystotelesowskiej wykładni wyobraźni zob. G. Watson, Phantasia in Aristotle, „De Anima” 3.3, „The Classical Quartely”, 32 (1982), nr 1, s. 100-113. Zob. również G. Watson, Phantasia in Classical Thougt, Galway 1988; R. Webb, Ekphrasis, Imagination and Persuasion in Ancient Rhetorical Theory and Practice, Farnham (Surrey) 2009, s. 107-130.

31 Arystoteles, $O$ duszy, 428b, s. 121.

32 Zob. E. Tesauro, Filosofia morale derivata dall'alto fonte del grande Aristotele Stagirita, Torino, per Bartolomeo Zapata, 1670, s. 26.

33 S. Petrycy z Pilzna, Przydatki do Etyki Arystotelesowej, w: Id., Pisma wybrane, t. I, oprac. W. Wąsik, Kraków 1956, s. 109. 
sa, doskonale znana i eksploatowana przez Francesca Patriziego ${ }^{34}$, przeprowadzająca znamienne rozgraniczenie pomiędzy fantazją retoryczną, dążącą do odzwierciedlania realiów, a ignorującą zasadę probabilizmu fantazją poetycką. „Fantazje poetów - konstatował Longinos, kładąc fundamenty pod renesansową poetykę cudowności — przechylają się w stronę baśni i wychodzą poza wszelkie prawdopodobieństwo, natomiast w fantazji retorycznej najpiękniejsze jest to, co pochodzi z życia i odpowiada rzeczywistości” ( $O$ górności XV). Nie ma wątpliwości, że w tej wykładni funkcje fantazji poetyckiej wykraczają poza, zawężony do probabilistycznej imitacji, sens mimesis.

Konkurencyjne wobec formuły mimesis, znane i cytowane przez teoretyków, jest także efektowne twierdzenie Filostrata: „wyobraźnia jest mędrszą artystką od naśladowania”, gdyż „mimesis przedstawia to, co widziała, a fantazja także to, czego nie widziała" ${ }^{35}$. W tej, zdawałoby się, bezkompromisowej wobec mimetyzmu konstatacji ${ }^{36}$ odbija się znamienna dla estetyki hellenistycznej koncepcja naśladowania kreacyjnego, nieograniczonego do odtwarzania zmysłowo dostępnej rzeczywistości ${ }^{37}$. Pojęcie fantazji, konotujące twórczy aspekt działalności artystycznej, jest swego rodzaju alternatywą dla mniej „artystycznej”, bo odtwórczej mimezy. Jak widać, to już teoretycy antyku, wyprzedzając renesansowych zwolenników artystycznej kreacji, zapoczątkowali ten-

34 Zob. S. Salomone, Influenze del „Sublime” ps longiniano sulla „Deca Ammirabile” di Franceso Patrizi da Cherso, „Studi Umanistici Piceni”, 16 (1966), s. 101-107.

35 Cyt. za: W. Tatarkiewicz, Historia estetyki, t. I, Wrocław 1962, s. 227, 286. Przytoczone wyżej cytaty pochodzą z Vita di Apollonio di Tyana (VI, 19) Filostrata.

36 Dla ścisłości, należy zaznaczyć, że stwierdzenia te nie są równoznaczne z koncepcją mimetyzmu fikcjotwórczego, zakładającą, iż swoboda poetyckiej inwencji ograniczana jest tylko zasadą - dosyć elastycznego — probabilizmu i regułą wewnętrznej koherencji dzieła. Taka koncepcja zostanie sformułowana dopiero przez Francesca Patriziego i później przez teoretyków konceptyzmu. Myśl Filostrata w takiej postaci, w jakiej przywołuje ją Władysław Tatarkiewicz w swym wywodzie, rzeczywiście może sugerować niemal brak granic inwencyjności poetyckiej fantazji. Jednak jej dopełnienie, jakie czytamy w dalszej części tekstu Filostrata, dosyć wyraźnie ogranicza tę kreacyjną swobodę fantazji, wskazując jako fundamentalny system odniesienia fantazyjnych wytworów realną rzeczywistość: „[...] wyobraźnia [...] przyjmuje to, czego nie widziała, opierając się na analogii z bytem" (W. Tatarkiewicz, Estetyka starożytna, s. 348). Szerzej na temat antymimetycznych koncepcji Filostrata pisze A. Manieri, op. cit., s. 60-66.

37 Zob. B. Otwinowska, Imitacja. Zarys problematyki i ewolucja pojęcia, w: Problemy Literatury Staropolskiej, seria II, red. J. Pelc, Wrocław 1973, s. 384. 
dencję do podkreślania opozycji między tworzeniem o rodowodzie imaginacyjnym a mimetycznym odtwarzaniem rzeczywistości wedle zasad probabilizmu.

Skłonność do marginalizowania, a co za tym idzie - niskiego waloryzowania odtwórczego charakteru sztuki poetyckiej wyjątkowo zdecydowanie wybrzmiewa $\mathrm{w}$ późnorenesansowych polemikach związanych $\mathrm{z}$ utożsamianiem pojęcia mimesis $\mathrm{z}$ reprezentacją unaoczniającą - Arystotelesowską kategorią pro ommaton poiein i greckim pojęciem enargeia $^{38}$. Niefortunna identyfikacja mimesis z enargeją, o której dziś wiadomo, że była konsekwencją błędnego odczytania dwóch terminów w passusie Retoryki (1412a) Arystotelesa ${ }^{39}$, budzi ostry sprzeciw teoretyków opowiadających się po stronie kreacyjnych działań poetyckich. Przeciwko redukcji poetyckiego naśladowania do przedstawienia unaoczniającego i minimalizacji roli poety do reprodukcji wizualnych efektów najwcześniej występuje Giovanbattista Giraldi Cinzio. Kwestia twórczej aktywności wyraźnie wyodrębniana w Discorso intorno al comporre dei romanzi pozwala zaliczyć koncepcje Cinzia do grupy poetyk hołdujących przekonaniu o kreacyjnym charakterze procesu poezjotwórczego i fikcjotwórczej mocy poetyckiej wyobraźni ${ }^{40}$.

Teoretyk romansu zdecydowanie preferuje taką odmianę mimetyzmu, która nie będzie ograniczona do działań imitacyjno-reprodukcyjnych, odtwarzania czy „powtarzania” rzeczy znanych, lecz polegać będzie na powoływaniu do istnienia fikcyjnych wytworów imaginacji, tworzeniu i „wymyślaniu na nowo”. Dlatego jedynym adekwatnym dla poety przydomkiem może być „twórca” — facitore („Parocchè questo

38 Na temat związku mimesis i enargei w teoriach antycznych zob. R. Webb, op. cit., s. 127-128; o renesansowych reduplikacjach terminów stosowanych na oznaczenie reprezentacji rzeczywistości pisze T. Cave, Enargeia. Erasmus and the Rhetoric of Presence in the Sixteenth Century, „L'Esprit Créateur”, 16 (1976), nr 4, s. 5-6. Zob. również F. Rigolot, The Rhetoric of Presence: Art, Literature and Illusion, w: The Cambridge History of Literary Criticism, vol. III, ed. by G. A. Kennedy, G. P. Norton, Cambridge 1999, s. 161-164; B. Hathaway, op. cit., s. 29-30.

39 Zob. m.in. A. Manieri, op. cit., s. 102; G. Zanker, Enargeia in the Ancient Criticism of Poetry, „Rheinisches Museum für Philologie”, 124 (1981), s. 301. Problem utożsamienia mimesis i enargei w teoriach późnego renesansu omawiam w przygotowywanej do druku monografii poświęconej kategoriom enargei i energei.

40 Zob. B. Hathaway, op. cit., s. 303-389; J. M. Steadman, Image-Making in the Verbal and Visual Arts: A Renaissance Obsession, „The Huntington Library Quarterly”, 61 (1998), nr 1, s. 58-69. 
nome di poeta non vuol dir altro che facitore" $)^{41}$. Krytyczny stosunek Cinzia do odtwórczej mimezy ujawnia się w znamiennym sformułowaniu jednoznacznie wskazującym działania gwarantujące twórcy miano poeta facitore i zarazem określającym istotę aktu twórczego: „Jeśli poeta jedynie brałby rzeczy już gotowe, a nie wymyślał ich na nowo, utraciłby imię poety, dlatego, że nie tworzyłby, a jedynie powtarzał rzecz już wykonaną" ${ }^{42}$. Wyłaniająca się z tych twierdzeń apologia kreacyjnego aspektu twórczości w sposób naturalny wyklucza koncepcję sprowadzającą mimetyczną aktywność do wizualizacji imitowanych przedmiotów. Dlatego Cinzio zdecydowanie neguje twierdzenie Marca Girolama Vidy upatrującego istotę aktu poetyckiego $\mathrm{w}$ reprezentacji unaoczniającej ${ }^{43}$. Atrybut kreacyjności, stanowiący, wedle Cinzia, esencję poetyckiej aktywności, zdradzają już choćby znamienne określenia, jakimi posługuje się teoretyk dla oddania charakteru twórczej aktywności poety. Stosowane zazwyczaj w kontekście mimesis określenia typu imitare, rappresentare czy rassomigliare nieprzypadkowo zastępuje znamiennymi terminami fingere i fare (wytwarzać), które ewidentnie wskazują na kreacyjne funkcje poetyckiego naśladowania.

Cinzio nie był jedynym twórcą zdecydowanie występującym przeciw identyfikacji mimesis z przedstawianiem unaoczniającym. Redukcjonistyczna teoria tworzenia, sprowadzająca poezję do probabilistycznej imitacji realiów albo - co gorsza — do imitowania wizualnych walorów rzeczywistych przedmiotów, najżywszą reakcję sprzeciwu wzbudzi oczywiście u Francesca Patriziego, konsekwentnie zmierzającego w swych pismach do dezawuacji i deprecjacji arystotelesowskiej doktryny mimetycznej. Podstawowym defektem, wskazywanym przez Patriziego w wywodach Stagiryty dotyczących naśladowania jest niedostatek argumentów dowodzących słuszności tezy o tożsamości procesu poezjotwórczego i mimetycznego oraz brak precyzyjnej, jednoznacznej eksplikacji pojęcia mimesis. Zarzut niejednoznaczności stawia Arystotelesowi zresztą nie tylko Patrizi; już wcześniej podobną krytykę wyraził słynny

41 J. Mazzoni Discorso al comporre dei romanzi distinta in sette libri, studi e spesa Mauro Verdoni e Domenico Buccioli, Cesena, per Severo Verdoni, 1688, s. 63.

42 Por. „Che s'egli solo si prendesse le cose fatte e non ne fingesse di nuove, prederebbe il nome del poeta, parocchè non farebbe ma solo reciterebbe il fatto [...]" (ibidem, s. 63).

43 „[...] dal qual porre la cosa inanzi non ha avuto il poeta il nome, come si ha creduto il Vida nel secondo della sua Poetica" (ibidem). 
komentator Poetyki - Lodovico Castelvetro, dostrzegając w traktacie brak konkretnych wskazówek, które umożliwiłyby aplikację zalecanych przez Stagirytę teorii w praktyce twórczej ${ }^{44}$. Mimo to Patrizi ma pretensję do Castelvetra (i nie tylko do niego, bo zarzutów nie szczędzi tym wszystkim, którzy teorię mimesis inercyjnie przejmują i akceptuja) o to, że ów niezliczoną ilość razy stosuje terminy imitazione i rapprezentazione, twierdząc, że poezja jest naśladowaniem, lecz nie raczy wyjaśnić, co właściwie miałoby to znaczyćc ${ }^{45}$.

Włoski teoretyk cudowności skrupulatnie ekscerpuje z pism Arystotelesa różnorodne i — jak nie omieszka zauważyć — nieprecyzyjne znaczenia terminu mimesis, które z bezlitosną logiką podważa, wskazując ich absurdalność. Główny kontrargument Patriziego jest niekwestionowalny: produkcja naśladowczych przedstawień jako czynność właściwa nie tylko poecie, lecz także wielu innym twórcom, nie może stanowić differentia specifica poezji, tym bardziej nie powinna być postrzegana jako istota aktu twórczego ${ }^{46}$. Ostateczny wniosek znajduje wyraz w ostentacyjnie antymimetycznych konstatacjach:

Adunque la rassomigliante imitazione non forma la poesia. Adunque le poesie non sono imitazioni. Adunque non buono, nè vero è lo 'nsegnamneto aristotelico, che tutte le poesie sieno imitazioni [...] Ed in somma noi diciamo che non sia vero il dogma che la poesia tutta sia imitazione. ${ }^{47}$

W podobny sposób rozprawia się Patrizi z identyfikacją naśladowania i przedstawienia unaoczniającego, gdyż stwierdza najpierw, że istnieje niezliczona liczba tekstów poetyckich pozbawionych walorów ewidencji, które mimo to niewątpliwie są poezją. Następnie dodaje, że gdyby rzeczywiście wizualizacja stanowiła istotę poezji, wówczas każdego

44 Zob. L. Castevetro, Poetica d'Aristotele vulgarizzata e sposta, a cura di W. Romani, Bari 1978, m.in. s. 480.

45 F. Patrizi, La deca disputata..., s. 65.

46 Antymimetyczne wystąpienie Patriziego omawiają m.in. B. Hathaway, op. cit., s. 9-22 i B. Weinberg, op. cit., vol. II, s. 765-773.

47 „A zatem upodobniające naśladowanie nie tworzy poezji. A zatem, poezje nie są imitacjami. A zatem, nie jest ani dobra ani prawdziwa nauka arystotelesowska o tym, że każda poezja jest naśladowaniem [...]. I w końcu twierdzimy, że nie jest prawdziwym dogmat mówiący, że poezja jest naśladowaniem" (F. Patrizi, La deca disputata, s. 85,89$)$. 
zdolnego opowiadacza, historyka czy sugestywnego mówcę należałoby nazwać poetą — imitatorem ${ }^{48}$. Ten niepodważalny argument Patriziego wykorzysta kilkanaście lat później Paolo Beni w swych eksplikacjach poetyki Arystotelesa, ostatecznie kwestionując sens ograniczania poetyckiego naśladowania do unaoczniającej imitacji wizibiliów ${ }^{49}$.

Przywoływane tu przykłady późnorenesansowych polemik z mimetyzmem wyraźnie pokazują, że odtwórczy aspekt naśladowania, któremu odpowiada mimesis eikastyczna i spokrewniona z nią kategoria enargei, jest przez włoskich apologetów kreacyjno-fantastycznego wymiaru twórczości oceniany zdecydowanie niżej niż artystyczna fikcja i kreacja, albo — co raczej wyjątkowe i właściwe jedynie Patriziemu — zaciekle zwalczany. O ile jednak apoteozy mimetycznej kreacji w rodzaju tych, które formułował Cinzio, jedynie modyfikują tradycyjną doktrynę, to kontestacja teorii identyfikującej poezję z mimesis, dokonana przez $\mathrm{Pa}-$ triziego, prowadzi do sformułowania konkurencyjnej i alternatywnej wobec mimetyzmu teorii cudowności, w której główną rolę odgrywa właśnie kreacyjna wyobraźnia. Naturalną konsekwencją zmiany optyki postrzegania aktu twórczego jest zakwestionowanie sensowności nadawania poecie miana imitatore - skoro „poezja znaczy nie naśladowanie (imitazione), lecz wytwarzanie (facitura) "50, to poeta nie jest już naśladowcą, lecz wytwórcą (facitore).

Integracja doktryny mimesis z koncepcjami fikcji i twórczej fantazji zostaje ostatecznie zdekonstruowana - pojęcia naśladowania i tworzenia usytuowane są na dwóch przeciwległych biegunach, przy czym po jednej stronie mamy bierną odtwórczość, upodobniającą, eikastyczną mimetykę właściwą wielu twórcom, po drugiej — twórcze wytwarzanie, aktywną kreację przysługującą jedynie poecie realizującemu dyrektywę meraviglia. Wśród prerogatyw poety, który — przypomnijmy jest facitore del mirabile, znajduje się nie tylko przywilej wymyślania rzeczy nowych i nieznanych, a zatem możliwość przekraczania zasady probabilizmu, balansowania pomiędzy wiarygodnością a niemożliwoś-

48 Por. „Oltre a queste ragioni noi diciamo che chiunque affermasse la cotale rassomiglianza, o imitazione, formar le poesie, verrebbe a dire ch'ogni egregio favellatore, e ogni retorico dicitore, ed ogni istorico, facendoci quasi vedere davanti le cose di che parla, fosse poeta" (F. Patrizi, La deca disputata, s. 66).

49 P. Beni, In Aristotelis poeticam commentarii, Patavii, in Beniana, 1613, s. 57.

50 Fragment V księgi La deca disputata w tłum. T. Dobrzyńskiej, w: Poetyka okresu renesansu..., s. 413 . 
cią, ale również prawo transformowania i formowania rzeczywistości, nadawania rzeczom nowych kształtów ${ }^{51}$. Proces poezjotwórczy nie ma nic wspólnego z odtwórczą imitacją, określany jest jako finzione, formazione, figuramento, trasformazione, trasfigurazione (wymyślanie, wytwarzanie, kształtowanie, przekształcanie). Poeta, niczym Formatore del Universo, albo, przywoływany w teorii Lorenza Valli, garncarz wydobywający nowe formy z materii gliny ${ }^{52}$, wytwarza i kształtuje alternatywną rzeczywistość fikcji i cudowności.

Eksplikując sens poetyckiego wytwarzania, którego fundament stanowią działania fikcjotwórcze, a więc przede wszystkim czynność „wymyślania”, dokonuje Patrizi dokładnej analizy etymologicznej włoskiego terminu fingere, wywodząc go od greckiego $\pi \lambda \alpha \dot{\alpha} \tau \varepsilon \varepsilon v$ i z określoną intencją przywołując łacińskie odpowiedniki greckiego plastes - fictor, creator, conditor ${ }^{3}$. Wymyślanie (fingere) równoznaczne jest $\mathrm{z}$ tworzeniem (formare) i przekształcaniem natury, transformowaniem starej formy materii w nową:

[...] il poeta, che facitore si disse essere, quando finga ne suoi poemi, o formi, o trasformi la materia dalla sua prima forma in una nuova. Ed essendo egli, come dimostrato s'è, facitore del mirabile, sarà ancora fingitore, e formatore, $\mathrm{e}$ trasformatore di forma mirabile nel ciascuna sua poesia. ${ }^{54}$

51 Zob. F. Patrizi, La deca plastica, w: Id., Della poetica, vol. III, edizione critica a cura di D. Aguzzi-Barbagli, Firenze 1971, s. 19. Zob. również B. Weinberg, op. cit., s. 776.

52 Por. „Fingere proprie est figuli, qui formas ducit ex luto. Inde generale fit vocabulum ad caetera, quae ingenio, manuque hominis artificiose formantur, praesertim, inusitate et nove. Effingere est ad alterius formam fingere, et quodam modo fingendo repraesentare". Cyt. za: M. Baxandall, Giotto e gli umanisti. Gli umanisti osservatori della pittura in Italia e la scoperta della composizione pittorica 1350-1450, Milano 2007, s. 218-219.

53 Por. „[...] questo verbo fingere noi intendiamo per quello stesso che i Greci dissono

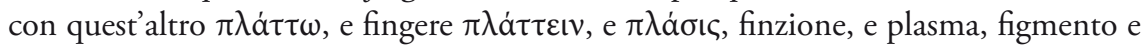
cosa finta. La quale plasis i Latini appellarono: fictio e formatio, e formatura; e l'artefice del fingere quelli dissero plastes, e questi fictor, creator, conditor. E nel significato loro compresero colui che o di cera, o di gesso, o di creta, o di argilla, o di stucco, o d'altra materia molle questa, o quella figura formava" (F. Patrizi, La deca plastica, s. 18).

54 Ibidem, s. 19. 
Poeta facitore, realizujący tak pojmowaną zasadę poetyckiej kreacji, upodobnia się więc do tych, którzy wytwarzają nowe formy, kształtując odpowiednio materię plastyczną (glinę, wosk, gips), oraz niewiele już ma wspólnego z imitatorem, który kształty jedynie odtwarza. Poeta imitatore naśladuje rzeczy zastane, facitore "robi to, czego nie było" 55 . Żaden $\mathrm{z}$ późnorenesansowych włoskich teoretyków nie odpowiada tak jednoznacznie na postawione w tytule tego szkicu pytanie. Patrizi, chwilami bliski w swym radykalizmie XX-wiecznej awangardzie spod znaku antysztuki, nie ma najmniejszych wątpliwości, że tworzenie i naśladowanie to działania całkowicie w swej istocie odmienne.

Tak zdecydowanie antymimetycznych głosów nie było w renesansie wiele, teoria Patriziego nie zyskała wielkiego oddźwięku, a powszechną recepcję uniemożliwiał fakt, że większość pism teoretyka pozostawała w rękopisach ${ }^{56}$ (odkrytych przez Paula Oscara Kristellera dopiero w XX wieku). Zresztą, wyłączając krótkie epizody ruchów innowacyjnych, ekstremizm rzadko kiedy był specjalnością dawnej teorii literackiej. Nie ulega jednak wątpliwości, że spośród dwóch wyróżnionych przez Platona odmian naśladowania późny renesans wybierał raczej twórczą mimesis fantastyczną, co widać zarówno w literackiej teorii, jak i w praktyce, gdzie prym wiodą poematy romansowe, daleko odbiegające od wiernego naśladowania eikastycznego.

Dodajmy jeszcze na koniec, że nieco inaczej wyglądała sytuacja w myśli teoretycznej w późnorenesansowej Polsce. Tu nikt nie miał szczególnych ambicji, by detronizować Arystotelesa, zaciekle zwalczać doktrynę naśladowania i jej zwolenników, czy atakować mimesis. Nie oznacza to jednak, że europejskie tendencje i aspiracje pozostały w Rzeczypospolitej bez echa. Preferencje i postawy polskich teoretyków nie były aż tak niewzruszenie, by nie powiedzieć — zachowawczo, promimetyczne, jak mógłby to sugerować brak bezpośredniej, otwartej polemiki z dominującą doktryną estetyczną. Ślady tendencji antyodtwórczych wskazać można wszakże w polskiej teorii dopiero w wieku XVII. I choć daleko im do ostentacyjnej bezkompromisowości postaw włoskich, to jednak nie ulega wątpliwości, że estetyka polskiego baroku skłania się wyraźnie w stronę aktywnego, kreacyjnego paradygmatu tworzenia, co najlepiej

55 W. Tatarkiewicz, Historia estetyki, t. III s. 370.

56 Zob. P. O. Kristeller, Eight Philosophers of Italian Renaissance, Stanford 1964, s. 114 . 
pokazuje przykład teorii Macieja Kazimierza Sarbiewskiego, który pisząc o naśladowaniu, nie tylko przywołuje Scaligerową analogię pomiędzy kreacją boską i poetycką, lecz także konsekwentnie stosuje terminy creare, fingere czy fare, obdarzając poetę nobilitującym przydomkiem factor, z tego względu, że „nie tylko przedstawia, ale wprowadza coś nowego" ${ }^{77}$. Dowartościowuje Sarbiewski także dyspozycję twórczej imaginacji, przestrzegając adeptów sztuki konceptu przed nazbyt rygorystycznym respektowaniem sztywnych reguł, które hamować mogą wyobraźnię ${ }^{58}$, niwecząc szanse na wykreowanie nowego, błyskotliwego konceptu.

A zatem po kilkudziesięciu latach od wystąpienia Patriziego mimesis sprowadzona jedynie do odtwórczego kopiowania rzeczywistości zejdzie na plan dalszy również w sarmackiej Rzeczypospolitej. Poeta factor wraz ze swymi twórczymi dyspozycjami, wyobraźnią, inwencją i ingenium, zacznie powoli i tutaj wyzwalać się spod pęt sztywnych rygorów tradycyjnej doktryny, by w końcu niemal całkowicie uchylić się od obowiązku probabilistycznego powielania rzeczywistości.

Krytyczne refleksje i estetyczne preferencje teoretyków prowokują do tego, by dyskusję z koncepcją mimetyczną i będące jej efektem jednoznaczne dowartościowanie kreacyjnego wymiaru twórczości, uznać za dystynktywny rys późnorenesansowej estetyki. Bez ryzyka przesady stwierdzić można, że sprzeciw wobec odtwórczej mimezy był w dobie kształtowania się nowożytnego systemu estetycznego czynnikiem determinującym rozwój eksperymentalnych koncepcji — najpierw cudowności, nieco później konceptu i barokowej, dynamicznej metafory. Późnorenesansowe tendencje ,antymimetyczne” poprzedziły eksperymenty estetyczne, stanowiąc niejako siłę napędową nowych pomysłów. Wszak Francesco Patrizi, nim sformułował rewolucyjną poetykę meraviglia

57 M. K. Sarbiewski, De perfecta poesi sive Vergilius et Homerus. O poezji doskonatej czyli Wergiliusz i Homer, przeł. M. Plezia, oprac. S. Skimina, Wrocław 1954, s. 10 (ks. I, 1). Szerzej na temat koncepcji poetyckiego kreacjonizmu w teorii Sarbiewskiego zob. A. Li Vigni, Invention and Creation in the Treatise "De perfecta poesi” of M. C. Sarbiewski, w: Maciej Kazimierz Sarbiewski i jego epoka. Próba syntezy, red. J. Z. Lichański, Pułtusk 2006, s. 107-132; M. Prejs, Problemy kreacjonizmu w myśli teoretycznej Macieja Kazimierza Sarbiewskiego, w: ibidem, s. 153-166.

58 M. K. Sarbiewski, De acuto et arguto sive Seneca et Martialis. O poincie i dowcipie czyli Seneca i Marcjalis, w: Id., Praecepta poetica. Wyktady poetyki, przeł. i oprac. S. Skimina, Wrocław 1958, s. 14. 
w La deca ammirabile, najpierw rozprawił się z mimetyczną doktryną Stagiryty w La deca disputata. XVI-wieczne apologie mimesis fantastycznej antycypowały XVII-wieczną absolutyzację ingenium, a sprzeciwy wobec jedynie odtwórczego wymiaru mimezy otworzyły możliwość barokowych transformacji Arystotelesowskiego systemu teoretycznoliterackiego. Trudno oprzeć się wrażeniu, że to rozpoczęta u schyłku XVI stulecia „walka” z naśladowaniem dała asumpt późniejszym teoretykom do formułowania koncepcji ignorujących podstawowe zasady klasycznej mimetyki.

\section{Poeta Imitatore or Poeta Facitore? Late Renaissance Italian Discussions about Mimesis}

The article presents the opposition to the imitative dimension of mimesis, one of the characteristic trends in Italian late Renaissance thought in literary theory. Examples of polemics against the traditional doctrine of mimesis (F. Patrizi i G. G. Cinzio), comments on Plato's concept of fantastic mimesis (G. Mazzoni, G. Comanini) and the terminological decisions of XVI c. theorists, willing to use the terms fingere and fare instead of the traditional imitare, show that in literary theoretical reflection at the time of the Renaissance appeared a clear appreciation of the fictionally creative aspect of poetic work. The creative dimension of the poets' craft, utilizing creativity and imagination, is preferred and valued incomparably higher than the copy-cat method of "creating images" at the end of the XVI c.

Translated by Agnieszka White 